Volume: 06, Issue: 06 "November-December 2020"

\title{
A STUDY ON ROLE OF WOMEN IN WATERSHED MANAGEMENT ACTIVITIES IN UTTARKASHI AND BAGESHWAR DISTRICT OF UTTARAKHAND
}

\author{
*Shikha Singh and Neelam Bhardwaj \\ Department of Agricultural Communication, G.B. Pant University of Agriculture \\ and Technology, Pantnagar, Uttarakhand (263145), India \\ *Corresponding author
}

DOI: https://doi.org/10.51193/IJAER.2020.6611

\begin{abstract}
In Uttarakhand mountain areas, the trend of men migrating to cities for job or their shifting to local salaried employment has created such space for women. Addressing gender and NRM together acknowledges the ecological imbalance and seeks to ensure that the contributions of both men and women are recognized to manage natural resources effectively and sustainably. Uttarakhand has been selected as the universe of the study. Out of 13 districts two districts namely Uttarkashi and Bageshwar were selected purposively as the locale for the proposed study. Data revealed that women played dominant role in the activities of nursery, organic manure, mulching and tree planting. These activities generally performed by women. Those activities which require physical strength, staying outdoors for long hours, traveling outdoors and negotiating with male members were performed by men. 69.66 per cent respondents reported reservation policy was the most effective measure to increase women participation in decision making.
\end{abstract}

Keywords: Gender, Natural resources, Participation, Decision making

\section{INTRODUCTION}

Since ancient times in Indian society the protection and importance of natural resources was prevalent. In Gurukuls the disciples were taught to worship plants, trees, mother earth, sky, air, water and animals. As philosophy of life it has been considered as the duty of the mankind to protect the nature. Atharva Veda considers earth to be the mother and other creations as its off springs. Man has no right to destroy the valuable creation of God. Respect for nature, environmental harmony and conservation through trees, mountains, and rivers are worshipped as 
International Journal of Agriculture and Environmental Research

ISSN: 2455-6939

Volume: 06, Issue: 06 "November-December 2020"

symbols of gods and goddesses like Varun Devta for water, Pawan Devta for air. One proverb in Gurubani, 'Pavan Guru Paani Pita, Maata Dharti Mahatu' also justifies, that means air is equated with teacher, water as father and great earth as mother. Thus the historical perspective depicted that people by and large were dependent on natural resources for their livelihood and survival. The permanent link between living beings and nature is to be sustained. Any strain in it would ruin the nature and made living beings to perish. Growing population puts a lot of pressure on the environment leading to fragile ecologies which make the farming systems unsustainable, risk prone and loss making. Deforestation, soil and water losses, climate change and decline in microbial population have called upon an urgent need for managing natural resources. The detoriation of these natural resources can be checked by well defined management practices leading to overall development of a particular region. Today watershed development is being promoted as an effective approach and an instrument for protecting the livelihoods of the people inhabiting the fragile ecosystems experiencing soil and moisture stress.

To reserve the order of deterioration of natural resources and support livelihood activities for the inhabitants, watershed management has been taken up as the functional and planning tool for conservation of natural resources and sustainable development by the Government of India through its Common Guidelines for Watershed Development Projects 2008. In the study area, Central Sponsored Scheme aided Integrated Watershed Management Project (IWMP) implemented by Watershed Development Directorate of Uttarakhand Government is operating since 2009 with the aim to restore the ecological balance by harnessing, conserving and developing degraded natural resources such as soil, vegetative cover and water with emphasis on women participation.

In Uttarakhand mountain areas, the trend of men migrating to cities for job or their shifting to local salaried employment has created such space for women. Empowered by movement like Chipko and through innovative projects or programmes like Mahila Samakhaya, Women Van Panchayats and Informal Women's Forest Committees, have come up into existence, particularly in the Garhwal region. Women have substantial legal rights in Van Panchayat but most of them have very little information about the funds or budgets for work undertaken in the village. (National Forest Policy, Ministry of Environment and Forest) clearly mentioned that women should be involved in achieving Integrated Watershed Management Project goals. However, in terms of gender there are no formal provisions and planning for women on executive committee, governing bodies and official decision makers at the village level under natural resource management projects. Addressing gender and NRM together acknowledges the ecological imbalance and seeks to ensure that the contributions of both men and women are recognized to manage natural resources effectively and sustainably (UNCED, 1992). Women have a unique 
International Journal of Agriculture and Environmental Research

ISSN: 2455-6939

Volume: 06, Issue: 06 "November-December 2020"

understanding of natural resources but not specifically included into the design of policies and programmes.

Therefore, there is a need to understand how important it is to consider women perspective in projects that focus on management of natural resources. When planners and projects staff recognize this and integrate women's concerns at all stages, it will lead to greater success of project

In view of above, the present study has been planned with the objective to study the role of women in watershed management activities and measures taken by government for increasing women participation in watershed management project.

Mrs. Pushpa Devi was a resident of tallihat village of bageshwar district. She was elected Sarpanch of tallihat gram panchayat as seat was reserved for women, in the year 2010. She was actively participated in meetings and trainings organized under project. She revealed that her communication skills improved and she confidently shared her views in front of project officials. She expressed that initially her husband took all the decisions about funds, management, problems and developments in the area on her behalf and she worked just as signatory authority but now he recognized her capabilities and provided her space and support to develop her decision making skills.

\section{MATERIALS AND METHODS}

The present paper has been based on primary data. Uttarakhand has been selected as the universe of the study. There are 13 districts in Uttarakhand which are grouped into two divisions: Kumaon and Garhwal. Out of 13 districts two districts namely Uttarkashi and Bageshwar were selected purposively as the locale for the proposed study. There are Krishna; Muradi and Bhatiya villages from Uttarkashi district and Tallihat, Matena and Kausani from Bageshwar district were selected using simple random sampling. A detailed primary survey of the study area had been conducted and from these six villages 300 respondents were selected by using PPS (Probability Proportionate to Size) method. For the collection of data, a structure schedule was developed for the respondents. Primary data had been collected by conducting interviews with 150 women and 150 men in six selected villages located within the watershed.

\section{RESULT AND DISCUSSION}

ROLE OF WOMEN IN WATERSHED MANAGEMENT ACTIVITIES: 
International Journal of Agriculture and Environmental Research

ISSN: 2455-6939

Volume: 06, Issue: 06 "November-December 2020"

Table 1: Distribution of respondents on the basis of their role in watershed management activities

$(\mathbf{n}=\mathbf{3 0 0})$

\begin{tabular}{|l|l|c|c|c|}
\hline S.No & \multicolumn{1}{|c|}{ Activities } & $\begin{array}{c}\text { Dominant role } \\
\text { No. }(\%)\end{array}$ & $\begin{array}{c}\text { Supportive role } \\
\text { No. }(\%)\end{array}$ & $\begin{array}{c}\text { No role } \\
\text { No. }(\%)\end{array}$ \\
\hline 1 & Doing terracing & $45(15.00)$ & $100(33.33)$ & $155(51.66)$ \\
\hline 2 & Making counter bund & $68(22.66)$ & $207(69.00)$ & $25(8.33)$ \\
\hline 3 & Building broad bund & $30(10.00)$ & $136(45.33)$ & $134(44.66)$ \\
\hline 4 & Developing slopping land & $26(8.66)$ & $152(50.66)$ & $122(40.66)$ \\
\hline 5 & Construction of stone barrier & $39(13.00)$ & $139(46.33)$ & $122(40.66)$ \\
\hline 6 & Nursery raising & $150(50.00)$ & $136(45.33)$ & $14(4.66)$ \\
\hline 7 & Application of organic manure & $148(49.33)$ & $132(44.00)$ & $20(6.66)$ \\
\hline 8 & Mulching \& tree planting activity & $162(54.00)$ & $123(41.00)$ & $15(5.00)$ \\
\hline
\end{tabular}

Data presented in Table 1 clearly shows that women played dominant role in the activities of nursery, organic manure, mulching and tree planting. These activities generally performed by women. Those activities which require physical strength, staying outdoors for long hours, traveling outdoors and negotiating with male members were performed by men. Women played supporting role in terracing, counter bed, broad bed, slopping land and stone barrier activities because these requires use of heavy implements, physical exertion. The women also perform the household chores in addition to the above discussed activities. Unlike field wok, household work was done around the year.

It was surprising to see that majority of the participation in labour allocation activities were done by women but still they performed supportive role in farm operations and all the decisions regarding farm related activities were dominant by men due to this, involvement of women in decision making was very limited. Devi et al. (1991) briefed in their study that the preparation of nursery, manuring, plant protection to nursery (24\%), $19 \%$ and $18 \%$ of the farm women performed only supervisory role respectively. Moser (1989) identifies women participation in the watershed management is usually on voluntary basis and it is unpaid work undertaken in their free time.

AWARENESS ABOUT WATERSHED MANAGEMENT ACTIVITIES: 
International Journal of Agriculture and Environmental Research

ISSN: 2455-6939

Volume: 06, Issue: 06 "November-December 2020"

Table 2: Distribution of respondents on the basis of their awareness about Integrated Watershed Management Practices

$(n=300)$

\begin{tabular}{|l|c|c|c|}
\hline S. No. & Response & Frequency & Percentage \\
\hline $\mathbf{1}$ & Yes & 234 & 78 \\
\hline $\mathbf{2}$ & No & 66 & 22 \\
\hline
\end{tabular}

Data regarding awareness about watershed management activities in their area is presented in Table 2. It is revealed from the data that maximum number of respondents ( 78 per cent) were aware about watershed management practices while 22 per cent of respondents reported that they were not well aware know about watershed management practices.

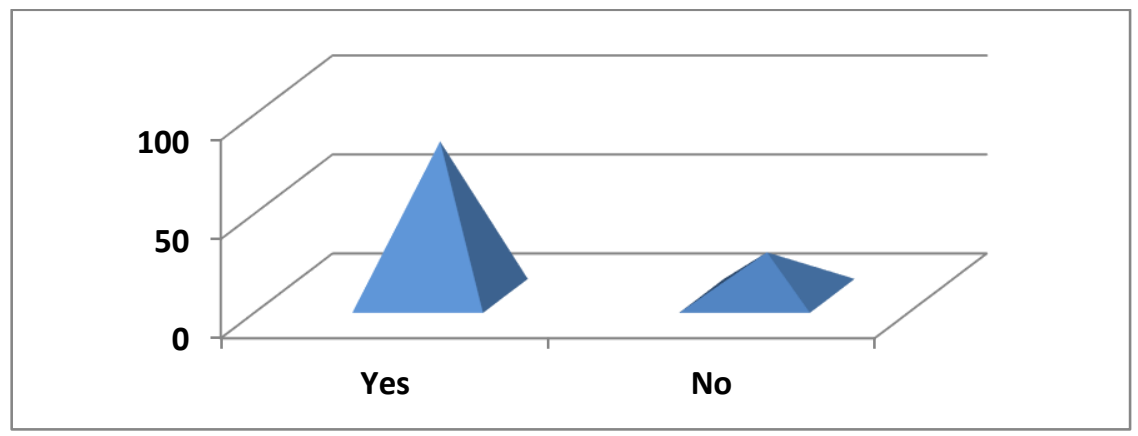

Distribution of respondents on the basis of Awareness

Table 3: Distribution of respondents on the basis of institutional arrangements to increase women participation

$(\mathrm{n}=150)$

\begin{tabular}{|l|l|c|c|c|c|}
\hline S.No. & Institutional Arrangements & $\begin{array}{c}\text { Always } \\
\mathbf{f}(\%)\end{array}$ & $\begin{array}{c}\text { Sometimes } \\
\mathbf{f}(\boldsymbol{\%})\end{array}$ & $\begin{array}{c}\text { Never } \\
\mathbf{f}(\boldsymbol{\%})\end{array}$ & $\begin{array}{c}\text { Weighted } \\
\text { mean score }\end{array}$ \\
\hline $\mathbf{1 .}$ & Information regarding latest practices & $100(66.67)$ & $40(26.67)$ & $10(6.67)$ & 2.6 \\
\hline $\mathbf{2 .}$ & $\begin{array}{l}\text { Information regarding meeting } \\
\text { communicated timely }\end{array}$ & $97(64.74)$ & $45(30)$ & $8(5.33)$ & 2.59 \\
\hline $\mathbf{3 .}$ & $\begin{array}{l}\text { Timing of meetings convenient to } \\
\text { women }\end{array}$ & $62(41.33)$ & $83(55.33)$ & $5(3.33)$ & 2.38 \\
\hline $\mathbf{4 .}$ & $\begin{array}{l}\text { Women participate in meeting to } \\
\text { select women representative in WMC }\end{array}$ & $54(36)$ & $76(50.67)$ & $20(13.33)$ & 2.22 \\
\hline $\mathbf{5 .}$ & Women equally involve in the & $99(66)$ & $46(30.36)$ & $5(3.33)$ & 2.62 \\
\hline
\end{tabular}


International Journal of Agriculture and Environmental Research

ISSN: 2455-6939

Volume: 06, Issue: 06 "November-December 2020"

\begin{tabular}{|l|l|l|l|l|l|}
\hline & formation of SHGs or WGs & & & & \\
\hline 6. & Frequency of PIA visits & $28(18.67)$ & $40(26.67)$ & $82(54.67)$ & 1.64 \\
\hline
\end{tabular}

$\mathrm{WMC}=$ Watershed management committee

$\mathrm{SHG}=$ Self-help group

$\mathrm{WC}=$ Women group

A cursory look at the Table 3 indicates that women equally involved in the formation of SHGs or WGs which ranked I with highest weighted mean score (WMS 2.62), Information regarding latest practices under IWMP was frequently received by the respondents with the WMS of 2.6, ranked II, followed by information regarding meetings communicated timely to the women (WMS 2.59) ranked III. The maximum number of respondents opined that the timing of meetings sometimes convenient to women (WMS 2.38, ranked IV). It was also observed that women sometimes participated in the meetings to select women representation in WMC (V, WMS 2.22). Data regarding regular visits of PIA to share information with beneficiaries received least weighted mean score (WMS 1.64), ranked VII. From the data, it can be concluded that along with PIA, it is the village watershed committee that was responsible for planning and decision making in watershed development projects. It was the responsibility of PIA to facilitate the participation of women in community activities by providing institutional arrangements such as childcare facilities, convenient time and venue of the meetings, information communicated timely. This might be an explanation of the requirement of institutional arrangements to enhance the active participation of women. In the line with this finding Njiriri C W (2011) reported that duration and timing of meetings are important aspects. Women can't easily stay away from home for longer periods, so a convenient timing and venue, allowing women to participate actively in community meetings.

Table 4: Distribution of respondents on the basis of Gender Mainstreaming policies under IWMP

$(\mathbf{n}=\mathbf{3 0 0})$

\begin{tabular}{|l|l|c|c|}
\hline S.No & \multicolumn{1}{|c|}{ Measure } & Frequency & Percentage \\
\hline $\mathbf{1}$ & Women facilitators & 22 & 7.33 \\
\hline $\mathbf{2}$ & Reservation policy & 209 & 69.66 \\
\hline $\mathbf{3}$ & Nominated to local decision bodies & 50 & 16.66 \\
\hline $\mathbf{4}$ & Women staff & 19 & 6.33 \\
\hline
\end{tabular}

There are some defined policies related to Gender Mainstreaming under IWMP. Data regarding measures taken under Integrated Watershed Management Project is presented in the Table 4. 
International Journal of Agriculture and Environmental Research

ISSN: 2455-6939

Volume: 06, Issue: 06 "November-December 2020"

According to the data 69.66 per cent respondents reported reservation policy was the most effective measure to increase women participation in decision making whereas 16.66 per cent reported that nomination to local decision bodies (elected as pradhan) was the second important measure to increase women participation in decision making in IWMP. Vasudha (1998) noted that women are nominated to watershed committees under a kind of 'reservation policy', implying that they are not members of the farming community in their own right. Few of the women 7.33 per cent and 6.33 per cent mentioned that women facilitators and increased number of women staff were the policies which affected women participation in IWMP.

It was observed that in the study area, women facilitators appointed to deal with women beneficiaries in the field level. Women facilitators helped to understand the problems and needs of women. Some changes were also observed that women become more comfortable and confident in expressing their views in public forum. It can be concluded that these policies in some extent played important role for the active participation of women in Integrated Watershed Management Project.

\section{Goat Farming}

Mr. Tulsi, a resident of Muradi village, district Uttarkashi and was from low income family. She was simple housewife and her husband was labour. She had very difficult time to manage the family requirements because of the only one earning member, her husband. After associated with SHG, she took decision to start goat rearing business to support a family of six members. She started her business of goat rearing six years back. She had formal training in goat rearing, which was provided by Directorate of Watershed Management, Uttarkashi. She felt that project helped her a lot, especially in financial aspect. After associated with project functionaries, she visited various places and learned latest developments and technologies in agriculture. She started her business with three goats. She brought goats with the help of watershed committee. Committee provided her Rupees 25000/- without any interest rate. Presently, she had fourteen goats and earned approximately 10000-15000/- at the time of sell. Initially, she faced some problems because of lack of communication with officials. Most of the officials directly communicated to Pradhan. But now, she felt confident to communicate their opinions and needs in meetings. She further expressed that she felt financially independent and earned money by her own where she was the decision maker. She admitted that project helped her to improve her socio-economic status in the society. She had not only been able to improve the economic condition of the family but also became more confident in dealing with people. When asked about her future plans, she said that she wanted to enter into vegetable growing business. However, her attitude has changed completely towards her role in upliftment of the family status. When her husband was asked about the change in life after her wife took up goat rearing, he 
International Journal of Agriculture and Environmental Research

ISSN: 2455-6939

Volume: 06, Issue: 06 "November-December 2020"

said, earlier the responsibility of the entire house on me, but now we both helped each other to fulfill family needs. I am proud of her that she took decision to do something of her choice.

\section{CONCLUSION}

It can be concluded that women's work in hill areas is strenuous and time consuming. In watershed management project most of the activities were carried out by women. This might be due to lack of off-farm practices and feasibility of agricultural pursuits in economic terms has triggered massive male outmigration. It resulted in shifting of adult members for jobs to support their families economically. Another observation was that women performed most of the labour work and engaged in agricultural operations, this trend was remained same. Men in hill region mostly indulged in non-productive activities like gossiping, consumed liqueur, gambling etc. This situation creates an imbalance as all the works were left for the women to perform and enhanced their participation in the region.

\section{LITERATURE CITED}

Devi, S., \& Mishra, N. R. 2013. Tribal Women Participation in Watershed Development Programme: A Case Study from Western Odisha. ADIVASI. 53(1-2):35-47

Moser, C.O.N. 1989. Gender planning in the third world: Meeting practical and strategic needs. World Development. 17(11): 1799-1825

Njiriri, C. W. 2013. Women's Role and Participation in Water Management : A Case of Kaiti Watershed in Makueni Kenya. Thesis, M.Sc. University of Nairobi. pp.6-7.

UNCED, 1992. Agenda 21: Programme of Action for Sustainable Development. New York: United Nations. 